Diabetologia 3, 1-8 (1967)

\title{
ORIGINALS
}

\section{Metabolism of Glycerol in Diabetes Mellitus*}

\author{
Risto Pelkonen, Esko A. Nikkin:̈ and Matti Kekki
}

\begin{abstract}
Third Department of Medicine, University of Helsinki and the Finnish Red Cross Blood Transfusion Service, Helsinki, Finland
\end{abstract}

Received March 1, 1966

\begin{abstract}
Summary. The metabolism of glycerol was studied by intravenous and oral glycerol tolerance test (single dose of $5 \mathrm{~g}$ orally and $2.4 \mathrm{~g}$ intravenously) in 15 healthy and 17 diabetic subjects. - The intestinal absorption of glycerol was rapid, the maximum serum level of glycerol occurring 15 minutes after the intake. In diabetic subjects the increment of serum glycerol was significantly smaller than in control cases. However, three patients with hyperlipemia and diabetes formed a striking exception in having abnormally high peak glycerol levels. The plasma FFA level was not altered by oral glycerol. Blood glucose remained unchanged in the controls, but rose on an average $13 \mathrm{mg} / 100 \mathrm{ml}$ in insulin-requiring diabetics. - The intravenous glycerol disappearance curves were analysed by an electronic computer. With a few exceptions the result was compatible with a one-compartment kinetic model. The fractional disappearance rate of glycerol from this pool was significantly smaller in diabetics $\left(0.041 \mathrm{~min}^{-1}\right)$ than in control subjects $\left(0.059 \mathrm{~min}^{-1}\right)$. However, the total disappearance rate was twice as high in the diabetic as in the control group (mean values 3.85 and $1.73 \mu$ moles per minute per kilogram, respectively).
\end{abstract}

Métabolisme du glycérol dans le diabète sucré.

Résumé. Le métabolisme du glycérol a été étudié à l'aide d'un test de tolérance au glycérol administré par voie intraveineuse et orale (dose unique de $5 \mathrm{~g}$ par voie orale et de $2.4 \mathrm{~g}$ par voie intraveineuse) chez 15 sujets en bonne santé et chez 17 diabétiques. - L'absorption intestinale du glycérol était rapide, le maximum du taux du glycérol sérique se produisant 15 minutes après la prise. Chez les sujets diabétiques l'augmentation du gly. cérol sérique était significativement plus faible que chez les sujets témoins. Cependant, trois patients atteints d'hyperlipémie et de diabète constituèrent une exception frappante, car ils présentaient des pics de glycérol anormalement élevés. Le taux des FFA du plasma n'était pas modifié par l'administration orale de glycérol. Le glucose du sang restait inchangé chez les sujets témoins, mais augmentait en moyenne de $13 \mathrm{mg} / 100 \mathrm{ml}$ chez les diabétiques nécessitant un traitement par l'insuline. - Les courbes de disparition du glycérol intraveineux furent analy- sées par un calculateur électronique. A quelques exceptions près, le résultat était compatible avec un modèle cinétique à un seul compartiment. La vitesse de la dispariţion fractionnaire du glycérol de ce pool était significativement plus faible chez les diabétiques $\left(0.041 \mathrm{~min}^{-1}\right)$ que chez les sujets témoins $\left(0.059 \mathrm{~min}^{-1}\right)$. Cependant la vitesse de disparition totale était deux fois plus élevée chez le groupe diabétique que chez le groupe témoin. (Valeurs moyennes respectives, 3.85 et 1.73 micromoles par minute et par kilogramme.)

\section{Der Glycerinstoffwechsel bei Diabetes mellitus.}

Zusammenfassung. Bei 15 Gesunden und 17 Diabetikern wurde der Glycerinstoffwechsel mittels intravenöser und oraler Glycerin-Toleranzteste (einmalige Gabe von $5.0 \mathrm{~g}$ oral und $2.4 \mathrm{~g}$ intravenös) untersucht. Die Resorption des Glycerins aus dem Darm erfolgte rasch; das Maximum des Serumglycerinspiegels wurde $15 \mathrm{~min}$ nach der Aufnahme erreicht. Bei Diabetikern war der Anstieg des Serumglycerins signifikant kleiner als bei den Kontrollpersonen. Drei Patienten mit Hyperlipämie und Diabetes bildeten jedoch eine auffallende Ausnahme insofern, als sie abnorm hohe Gipfel des Serumglycerins zeigten. Der FFA-Spiegel im Plasma wurde durch die orale Gly. cerinabgabe nicht verändert. Bei den Kontrollen blieb der Blutzucker unverändert, während der bei den insulinbedürftigen Diabetikern im Mittel $13 \mathrm{mg} \%$ anstieg. Die Kurven des Glycerinabfalls nach intravenöser Gabe wurden mit einem elektronischen Computer analysiert. Mit wenigen Ausnahmen war das Ergebnis mit einem kinetischen Modell mit einem Verteilungsraum vergleichbar. Die Abfallrate des Glycerins dieses Pools pro Minute war bei Diabetikern signifikant kleiner $\left(0.041 \mathrm{~min}^{-1}\right)$ als bei den Kontrollen $\left(0.059 \mathrm{~min}^{-1}\right)$. Der Gesamtabfall war jedoch bei den Diabetikern doppelt so stark wie bei der Kontrollgruppe (Mittelwerte 3.85 bzw. 1.73 micromol/ $\min / \mathrm{kg}$.)

Key-words: glycerol kinetics, serum glycerol, absorption of glycerol, intravenous glycerol test, oral glycerol test, serum triglyceride, plasma FFA, serum cholesterol, hyperlipemia, diabetes.
In spite of the low level of circulating glycerol its turnover has recently been shown to be rapid. Glycerol is readily converted to glucose and lipids or oxidized to $\mathrm{CO}_{2}$ by the animal organism. In fasting rats glycerol is possibly a major precursor of body glucose, and thus an essential source for glucomeogenesis [18].

* This work has been aided by grants from Yrjö Jahnsson Foundation, Sigrid Jusélius Foundation and Emil Aaltonen Foundation, Finland and the Finnish State Medical Research Cainal.
Fairly scanty attention has been paid to the metabolism of glycerol in human diabetes. The level of serum glycerol has been found to be elevated in uncontrolled diabetes and is lowered by insulin and/or glucose, as in subjects with normal glucose metabolism $[5,9,10,12]$. Opinions differ whether the lowering effect of glucose and insulin is mediated by reduction of glycerol output from adipose tissue or by increase of glycerol utilization. However, an accelerated production of glycerol from adipose tissue is evidently present in diabetics $[3,19]$, and insulin can inhibit in 
vitro, also in the absence of glucose, the epinephrinestimulated glycerol release from adipose tissue [16]. In liver slices obtained from alloxan-diabetic rats, AsmMore et al. [1] found a normal uptake of glycerol from the medium but a deficient production of glycogen from glycerol.

The present study was an attempt to get more information of the metabolism of glycerol in human diabetes. The kinetios of glycerol metabolism were studied by intravenous glycerol tolerance tests, and the intestinal absorption of glycerol was studied by oral glycerol tolerance tests. In both experiments non-labelled glycerol was used.

\section{Material}

The material consisted of hospital in-patients: 15 control subjects and 17 diabetic patients.

Diabetic Group. The following types of diabetes were included in the group: juvenile insulin-requiring, 9 cases; maturity-onset (controlled by oral hypoglycemic agents), 3 cases; maturity-onset obese, 2 cases; tinal malabsorption, such as diarrhoea, hypoproteinemia, etc. were included. The group consisted of 13 males and 4 females, the age of the patients ranged from 18 to 62 years.

Control Group. The group consisted of 10 male and 5 female patients admitted to the hospital because of minor non-metabolic illnesses, such as congenital heart disease without significant hemodynamic alterations or psychic and gastric disorders. Glucose tolerance, when checked, was normal as was renal function. The age of these subjects varied from 15 to 58 years.

\section{Methods}

The control subjects received an ordinary hospital diet consisting of about $200 \mathrm{~g}$ of earbohydrates daily. The diet of the diabetics had a calorie content equal to that of the controls but containing somewhat less carbohydrates (about $150 \mathrm{~g} /$ day). To check the possible effect of dietary differences, the oral glycerol test was made in one control subject on both diets but no differences were found.

Table 1. Fasting levels of blood glucose, serum triglyceride, cholesterol, glycerol and plasma FFA in 17 diabetic subjects and 15 control subjects

\begin{tabular}{|c|c|c|c|c|c|c|c|c|c|c|c|c|c|c|c|}
\hline & \multicolumn{3}{|c|}{$\begin{array}{l}\text { Glucose } \\
\mathrm{mg} / 100 \mathrm{ml}\end{array}$} & \multicolumn{3}{|c|}{$\begin{array}{l}\text { Triglyceride } \\
\mathrm{mg} / 100 \mathrm{ml}\end{array}$} & \multicolumn{3}{|c|}{$\begin{array}{l}\text { Cholesterol } \\
\mathrm{mg} / 100 \mathrm{ml}\end{array}$} & \multicolumn{3}{|c|}{$\begin{array}{l}\text { Glycerol } \\
\mu \text { moles/L }\end{array}$} & \multicolumn{3}{|c|}{$\begin{array}{l}\text { FFA } \\
\mu \text { moles } / \mathrm{L}\end{array}$} \\
\hline & $\overline{\text { Mean }}$ & S. D. & $p$ & Mean & S. D. & $p$ & Mean & S. D. & $p$ & Mean & S. D. & $p$ & Mean & S.D. $x$ & $p$ \\
\hline Diabetes & 204.3 & 65.6 & ( 0001$)$ & & 55.9 & $<0005$ & $230.3^{*}$ & 39.0 & $n s$ & 149.4 & 85.4 & 6001 & 885 & 292 & d] \\
\hline Control & 71.2 & 8.7 & & 89.0 & 34.8 & & 231.2 & 37.8 & & 71.8 & 32.4 & & $484 * *$ & 196 & \\
\hline
\end{tabular}

* 14 subjects ( 3 hyperlipemic patients excluded).

** 14 subjects.

$\mathrm{ns}=$ non-significant

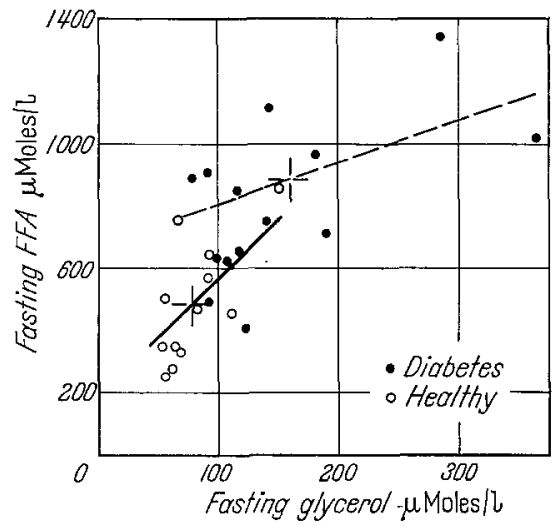

Fig. 1. Interreiationship between fasting levels of serum glycerol and plasma FFA in control (open dots) and diabetic (black dots) subjects. The lines indicate regression lines (continuous line, control group; dotted line, diabetic group). Regression equation in the control group: $y=0.194+0.3721 \mathrm{x}$ $\pm 0.16, r=0.60(p<0.05)$. The eorrelation was not significant in the diabetic group

and hyperlipemia with diabetic glucose metabolism, 3 cases. The patients were admitted to the hospital because of uncontrolled diabetes, but during the time of experiments the diabetes was adequately controlled. in all patients. No patients with signs indicating intes-
The insulin-requiring patients were given regular insulin twice daily (8.30 a.m. and 16.30 p.m.). Patients controlled by oral hypoglycemic agents were also put on regular insulin.

The glycerol tests as well as the determinations of the basal lipid levels were done after an overnight fast of 12 hours. The last insulin dose was given the previous afternoon, i.e., 15 hours before the test. The fasting levels of serum glycerol, cholesterol, triglyceride, blood glucose and plasma FFA were determined in all subjects.

Intravenous Glycerol Tolerance Test. In the test $2.4 \mathrm{~g}$ of glycerol (Glycerol pro inject "Star") was diluted with physiological saline to give a $10 \%$ solution and injected into a cubital vein over a period of 2 minutes. The serum levels of glycerol were determined over the subsequent 75 to 90 minutes at somewhat different intervals. Blood glucose and plasma FFA were determined before, and 30 and 60 minutes after the injection of glycerol.

The disappearance curve of serum glycerol was analysed by the aid of an electronic computer (model Elliot 503). For the computer analysis at least 6 venous samples were needed. 
Oral Glycerol Tolerance Test. In the test $5 \mathrm{~g}$ of glycerol (Glycerol bidest. "Merck") was given as a $5 \%$ aqueous solution. The serum levels of glycerol were determined at intervals of 15 minutes from 0 to 60 minutes after ingestion of glycerol. Blood glucose and plasma FFA were determined before, and 30 and 60 minutes after the load.

Analytical Methods. The following methods were used: glycerol by WLELAND [27] without precipitation of serum proteins; cholesterol by Pearsor et al. [20]; triglyceride by a combination of two methods $[11,4]$; blood glucose (capillary blood) by HYvärINeN and NTKkIL̈. [15]; and FFA by Trout et al. [25]. All analyses were done in duplicate.

\section{Results}

Basal levels (Table 1, Fig. 1)

In diabetic patients the fasting blood glucose varied from 124 to $306 \mathrm{mg} / 100 \mathrm{ml}$, whereas all control subjects were normoglycemic. When the three hyperglyceridemic cases (serum triglyceride levels 480, 1090 and $2525 \mathrm{mg} / 100 \mathrm{ml}$ ) were excluded, the diabetic group revealed a significantly higher mean level of serum triglyceride than controls whereas there was no difference in cholesterol levels. In spite of considerable overlap of the individual values, the mean levels of serum glycerol and plasma FFA were significantly higher in the diabetic group as compared with controls. A significant correlation between the fasting levels of glycerol and FFA was found to be present in the control but not in the diabetic group (Fig. 1).

Intravenous glycerol tolerance test (Table 2, Fig. 2 and. 3)

The intravenous test was carried out in 10 diabetics and 5 control subjects. For an understanding of the serum glycerol kinetics the data obtained from the intravenous experiments were treated in the manner described earlier by KEKKI [17] in connection with studies on the turnover of serum proteins. The primary assumption was that the disappearance curve of glycerol consisted of a sum of two or more exponential terms according to the general formula: $A_{1} e^{-a_{1} t^{t}}+$ $A_{2} e^{e^{-a}{ }^{t}}+\ldots A_{n} e^{-a_{n} t}$. The curve was divided into exponential components with the aid of an electronic computer. Two successive analyses of each curve were necessary to study the validity of two different kinetic models: firstly, beginning the analysis at the extrapolated zero-time, i.e., that point in time when the injection of glycerol was terminated $\left(t_{0}=0 \mathrm{~min}\right)$; and secondly, starting 10 minutes later $\left(t_{0}=10 \mathrm{~min}\right)$. The limits for the decay constants were $0.35 \mathrm{~min}$ and $\infty\left(10^{8} \mathrm{~h}\right)$. The two models under consideration were as follows:

A) Two-compartment model: By extrapolation of the disappearance curve to zero-time a kinetic model can be derived consisting of two compartments (intra- and extravascular pools), the mixing velocity between the pools, and influx and efflux of glycerol in one of the pools (extravaseular). If the model is valid the disappearance curve should be composed of three components, the half-life of the slowest being $\approx \infty$ indicating the level of serum glycerol at dynamic equilibrium.

B) One-compartment model: According to this model the intra- and extra-vascular pools make up only one common compartment. This is possible if the rate of mixing of glycerol is rapid enough in comparison with the efflux of glycerol from the compartment. In that instance, from kinetic point of view, the process of initial mixing can be neglected. Thus, the model estimates only influx and efflux of glycerol in a pool with a mathematically noncalculable size. To study the validity of the model $B$ the initial mixing was assumed to be completed within the first 10 minutes [23]. Therefore the disappearance curve was divided into its exponential components beginning from that point in time. According to this model, if valid, the disappearance curve after 10 minutes should be divisible into two components, the half-life of the second one being again $\approx \infty$. From the mathematical treatments performed in this manner, the following conclusions emerged.

Model A $\left(t_{0}=0 \mathrm{~min}\right)$. The mathematical treatment of the data of 6 disappearance curves gave rise to the expected 3 exponential terms with disappearance rate constants $k_{1}, k_{2}$ and $k_{3}$. Such a result suggests the presence of a two-compartment model. However, the derivation of the data obtained revealed biologically impossible results as regards the distribution and kinetics of glycerol in the given model. This event need not necessarily be due to an incorrect model, but may have its source in the technical limitations of the experiments; for example, 1 . the injection of glycerol was not instantaneous as was implied in the model; 2 . the sampling was too slow compared with the rapid initial disappearance of glycerol. Nevertheless, the rate constant, $k_{1}$, of the most rapid component can be used as an approximate indicator of the mixing velocity of glycerol in its distribution space. This seems to be mathematically well-grounded since two successive analyses of each curve gave almost identical results for the rate constant, $k_{2}$, of the second exponential component. Therefore $k_{1}$ will be used as the rate constant for the mixing process.

Model $\mathrm{B}\left(t_{0}=10 \mathrm{~min}\right)$. The analysis of the distribution curve beginning 10 minutes after injection was successful in 12 experiments. This means that only two components, with disappearance rate constants $k_{2}$ and $k_{3}$, were obtained corresponding to a simple kinetic model of efflux of glycerol and the state of dynamic equilibrium thereafter. The result is mathematically unambiguous and the disappearance rate constant $k_{2}$ thus obtained, can be considered as refering to the proper metabolism of glycerol: i.e., uptake and utilization of glycerol by the tissues. Therefore, the turnover rates of glycerol have been calculated according to the one-compartment model using $k_{2}$ as 
the disappearance rate constant for glycerol. Corresponding to the glycerol metabolism in such a onecompartment model the concentration of glycerol as a function of time can be expressed as follows:

$$
\begin{aligned}
& x=A_{2} \cdot e^{-k_{2} t}+A_{3} \cdot e^{-k_{3} t}, \text { which can be expressed } \\
& \text { when } k_{3} \ll 1 \text { as } \\
& x=A_{2} \cdot e^{-k_{2} t}+A_{3}, \text { and since } A_{2}+A_{3}=x_{0} \text { it } \\
& \quad \text { follows that } \\
& x=\left(x_{0}-A_{3}\right) e^{-k_{2} t}+A_{3} \\
& A_{3}=\text { total body glycerol content at equilibrium } \\
& x_{0}=\text { total body glycerol content at } t_{0} \\
& x=\text { total body glycerol content at } t
\end{aligned}
$$

By dividing the curve into exponential terms the numerical values for $A_{2}, A_{3}$ and $k_{2}$ can be obtained.

All experiments that at the end of the experiment obey the kinetic model (B) presented, have been accepted in the material. The material thus included two kinds of experiments: 1. pure disappearance curves consisting of only two exponential terms with rate constants $k_{2}$ and $k_{3} ; 2$. the disappearance curve that had in addition to these two components, a third very fast 'phantom-component', with a halflife not exceeding $0.35 \mathrm{~min}$. The presence of such a 'phantom-component' was considered to be chiefly due to an incomplete mixing of glycerol between intra- and extra-vascular pools, and this was not taken into account in the further calculations.

Three experiments ( 2 diabetic and 1 control) had to be omitted. In two of these the final component was positive, indicating mathematically that the content of glycerol levelled off at the end of the experiment at zero level, which is biologically impossible. In the
Rate constant $\left(k_{1}\right)$ of the mixing process. Since several samples taken at short intervals during the first minutes $(0,1,2,3,5,7$ and $9 \mathrm{~min})$ were necessary for an accurate calculation of the half-life of the very fast component, only 6 successful experiments were available. The values for the half-life in 3 control subjects were: $1.21,1.39$ and $1.74 \mathrm{~min}$; and in 3 diabetic patients ( 1 insulin-requiring and 2 maturity-onset types): $0.83,1.22$ and $1.29 \mathrm{~min}$. Thus no difference could be found in the value of $k_{1}$ between diabetics and controls.

Disappearance rate constant of glycerol $\left(k_{2}\right)$. The mean value for the half-life of the second exponential component was $11.6 \mathrm{~min}$ for the control group and 20.5 min for the diabetic group (Table 2; Fig. 2 and 3 ). Thus, the disappearance rate constant was significantly smaller in the diabetics $\left(0.041 \mathrm{~min}^{-1}\right)$ than in the control group $\left(0.059 \mathrm{~min}^{-1}\right)$. Independent of the type of diabetes, a reduced disappearance rate constant was found in all diabetics but one.

Attempts to calculate adequately the distribution space of glycerol by means of the computer were, as has been stated, unsuccessful, as were the trials by the conventional graphical means. However, the view that the distribution space of glycerol is equivalent to the total body water space is generally accepted. Therefore the constancy of the disappearance rate constant $k_{2}$, and the use of a value of $65 \%$ of the body weight as the distribution space of glycerol makes it possible to calculate the total turnover rate of glycerol. In spite of the smaller value for the disappearance rate constant, the diabetics had a turnover rate twice that for the controls (3.85 compared with $1.73 \mu \mathrm{moles} / \mathrm{min} / \mathrm{kg}$ ).

Table 2. The removal rates of glycerol in control and diabetic subjects. The distribution space of glycerol has been estimated to be 65 per cent of body weight

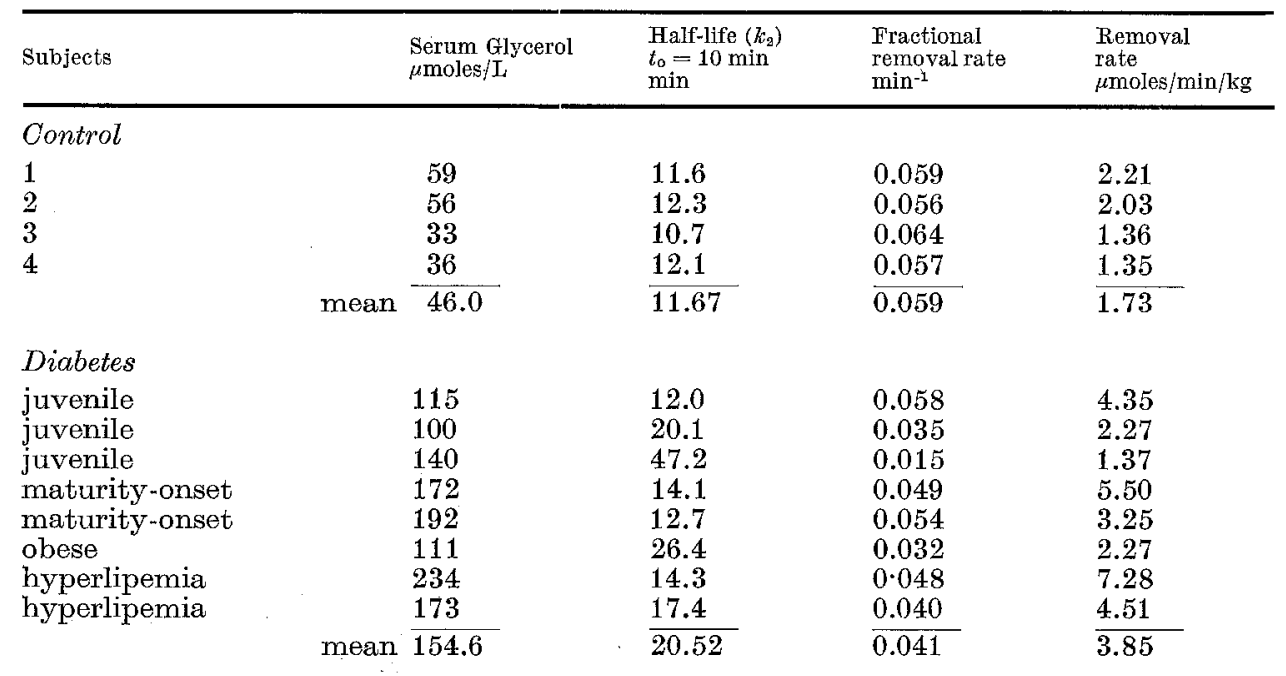

third, six components were obtained, which is incompatible with any kinetic model. Whether such events have any biological significance or are only due to technical errors is not known.
No significant differences were observed among the various types of diabetics as regards the total disappearance rate of glycerol.

State of Equilibrium $\left(k_{3}\right)$. The half-life correspond- 
ing to the rate constant, $k_{3}$, of the final exponential term $\left(A_{3} \cdot e^{-k_{3} t}\right)$ was in each experiment practically in finite. The coefficient $\left(A_{3}\right)$ corresponds the calculated level on which the level of serum glycerol laid down at the end of the experiment. The level varied from experiment to experiment, being in the control group on an average 20.6 and in the diabetic group 11.5 micromoles/L higher than the actual fasting level.

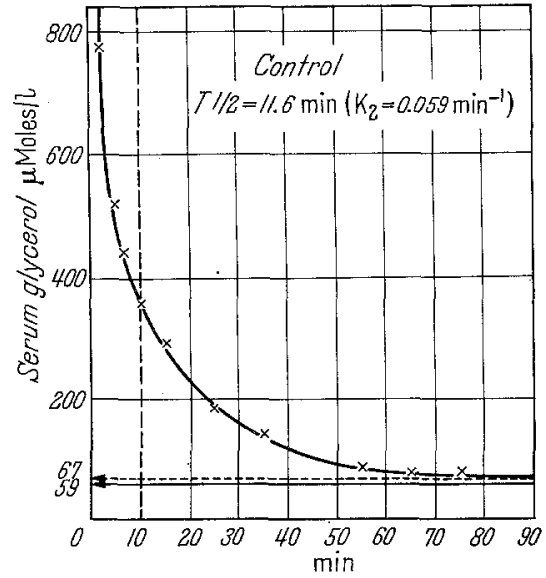

Fig. 2. Serum disappearance curve of glycerol after intravenous injection of $2.4 \mathrm{~g}$ of glycerol in a normal subject. The horisontal lines indicate serum glycerol levels; continuous line, pre-experimental; dotted line, calculated level at dynamic equilibrium

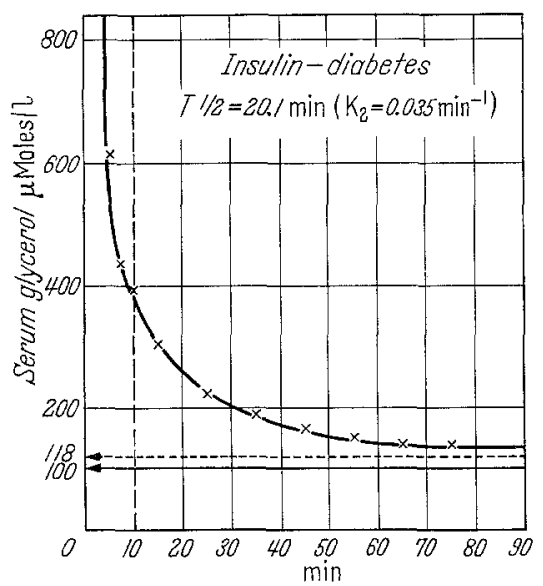

Fig. 3. Serum disappearance curve of glycerol after intravenous injection of $2.4 \mathrm{~g}$ of glycerol in an insulin-requiring diabetic subject. The horizontal lines indicate serum glycerol levels; continuous line, pre-experimental; dotted line, calculated level at dynamic equilibrium

According to the model $\mathrm{B}$, which presumes that the influx and the efflux of glycerol are constant during the experiment, the coefficient $A_{3}$ should decrease to the pre-experimental (actual fasting) level of serum glycerol. The calculated and the pre-experimental levels diverged by about 15 to 20 per cent on the average and in the same direction in both experimental groups of subjects, however. Although the exact reason for this event is not known, some explanations are available: 1 . Technical reasons (inaccuracy in sampling, methodological errors etc.); 2 . Inconstancy of the influx and efflux of glycerol during the first $10 \mathrm{~min}$ utes. On the other hand the mathematical resolution by the computer after 10 minutes timepoint was sharp and therefore the model $B$ fulfills the criteria to make a model mathematically valid.

Response of Blood Glucose and Plasma FFA to Intravenous Glycerol. Blood glucose and plasma FFA were determined before, and 30 and 60 minutes after the injection of glycerol in 14 experiments (9 diabeties, 5 controls) but no changes were observed.

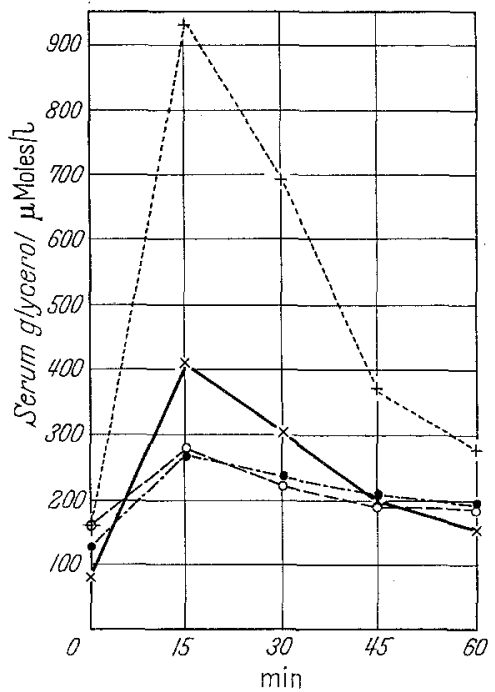

Fig. 4. Serum glycerol levels in 10 control and 15 diabetic subjects after ingestion of $5 \mathrm{~g}$ of glycerol. $\mathrm{x}-\mathrm{x}$, control subjects; $\mathrm{O}-\mathrm{O}$, insulin-requiring diabetics ( 8 cases); $0_{-}-0$, non-insulin diabetics (4 cases); $+\cdots+$, hyperlipemic subjects with secondary diabetes (3 cases)

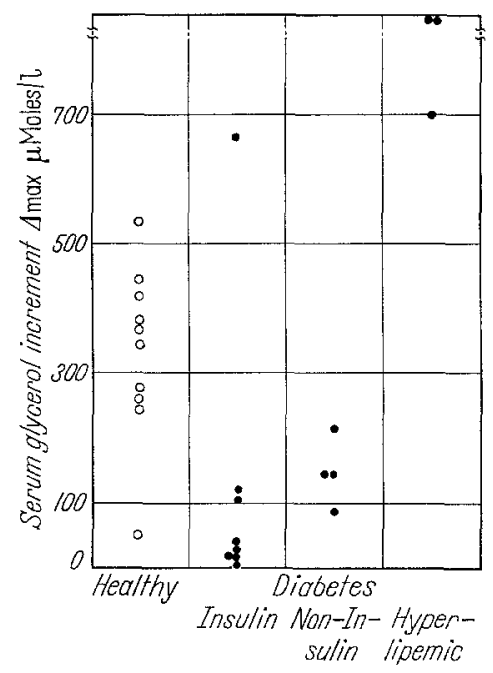

Fig. 5. Maximal increment of serum glycerol levels in 10 control and 15 diabetic subjects after ingestion of $5 \mathrm{~g}$ of glycerol

Oral Glycerol tolerance test (Fig. 4-6)

Serum Glycerol Levels. The intestinal absorption of glycerol appeared to be very rapid. In all but 2 subjects, i.e. 8 controls and 14 diabetics, the peak level of serum glycerol occurred as early as 15 minutes after the ingestion of glycerol. On the other hand, in only 4 subjects, all of them diabetics, the serum level of glycerol had returned to the starting level in one hour (Fig. 4). 
In diabetic subjects the increment of serum glycerol was significantly lower than in control cases. As a striking exception to this rule the three subjects with hyperlipemia and diabetes showed an extremely high peak-level of serum glycerol. There was only little overlapping between the control and diabetic groups of the individual values, indicating maximal increment of serum glycerol from fasting level (Fig. 5). One unexpected low value occurred in the control group in spite of normal glucose tolerance and one unexpected high value in the diabetic group. Since the serum fasting lipid levels were normal in the later case, no explanation is available for this finding.

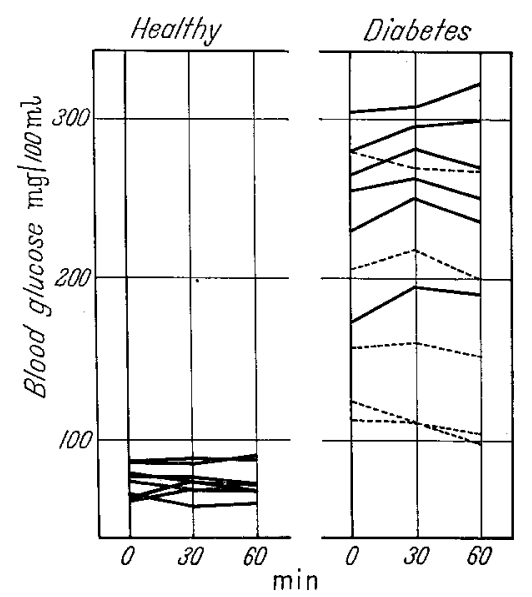

Fig. 6. Response of blood glucose to ingestion of $5 \mathrm{~g}$ of glycerol in control and diabetic subjects. Diabetic group: continuous lines, insulin-requiring diabetics; dotted lines, non-insulin diabetics

Response of Blood Glucose. The response of blood glucose to oral intake of glycerol was studied in 11 diabetic and 9 control subjects (Fig. 6). In the control group no change of blood glucose occurred. In contrast, all the insulin-dependent diabetics showed a small increase of blood glucose during the first $30 \mathrm{~min}$ utes, the mean increment being $13 \mathrm{mg} / 100 \mathrm{ml}$. The changes of blood glucose in the non-insulin requiring diabetics were inconsistent.

Response of Plasma FFA. Plasma FFA was determined in 10 diabetic and 9 control cases after ingestion of glycerol. The only consistent change noted was a fall in the 3 insulin-dependent diabetic subjects who also showed increment of blood glucose after glycerol load.

\section{Discussion}

The data obtained in the present study show that the body glycerol kinetics were altered in the diabetics at least in the following ways. 1 . The free glycerol mass of the body in the fasting state was increased; 2 . the disappearance rate of glycerol was decreased; 3 . the turnover rate of glycerol was accelerated; and 4 . an oral glycerol load caused a subnormal increase of serum glycerol level. However, peak serum levels that were abnormally high were observed following oral glycerol loading in cases of hyperlipemia with secondary diabetes.

The kinetics of glycerol metabolism deduced from the intravenous glycerol 'tolerance' test were compatible with a one-compartment model (model B) in which the distribution volume is apparently represented by the space corresponding to the total body water. An amount of exogenous glycerol added to this space via the blood mixes rapidly as is shown by the rate constant $\left(k_{1}\right)$ of the first exponential component of the equation describing the disappearance of the plasma glycerol. In the present experiments this component had a half-life of $1.4 \mathrm{~min}$. This value is in accord with the data of ScHWARz et al. [22], who reported the half-life of intravenous non-labelled glycerol in man to be about 2 minutes. On the other hand, this rate of dilution is higher than that observed by SHAFrrR and GoRIN [23] in whose experiments the equilibrium was not achieved before 15 minutes from the injection of the glycerol load. We have no explanation for the discrepancy between their curves and those obtained by us.

After the rapid mixing phase the disposal of glycerol followed first order kineties until the state of dynamic equilibrium was reached. This means that the elimination mechanisms are not saturated with a dose of glycerol approximately five times the endogenous glycerol mass, and, secondly, that the disappearance rate constant $\left(k_{2}\right)$ also represents the fractional turnover rate and can thus be used for the calculation of glycerol fluxes under steady state conditions. Presuming that the glycerol concentrations in cubital venous plasma and in total body water are equal in a resting subject, fasted overnight, the application of the individual values of $k_{2}$ gives an average glycerol turnover rate of $1.7 \mu$ moles $/ \mathrm{min} / \mathrm{kg}$ body weight for a normal man. Actually this procedure gives an overestimate of the true turnover because the samples used for analysis were drawn distally close to the sites of glycerol release (in this case the adipose tissue of the forearm). However, this value is very similar to those obtained earlier by other methods for both man and dog. Thus, Borcharevink and HAveL [2] measuring the arteriovenous difference across splanchnic area and the kidneys estimated the net removal of glycerol in these regions to be 60 to $130 \mu$ moles per minute, which gives a total efflux rate of 1 to $2 \mu$ moles per minute per $\mathrm{kg}$ for a subject of $60 \mathrm{~kg}$ assuming that no significant uptake of glycerol occurred at other sites. By a constant infusion of glycerol- ${ }^{3} \mathrm{H}$ HAVEL and CARLSON [12] arrived at exactly the same turnover rate figures in the dog. Calculation of the glycerol turnover rate from the data of SHAFRIR and GoRIN [23] gives a somewhat lower estimate $(0.7 \mu$ moles $/ \mathrm{min} / \mathrm{kg})$.

In diabetic subjects the fractional elimination rate of glycerol was found to be decreased whereas the endogenous glycerol turnover was accelerated. This means that the entry rate of glycerol is increased in 
diabetes while the efflux is relatively insufficient. The primary event must be the augmented production of glycerol, and this is also fully supported by the demonstration that glycerol release from adipose tissue incubated in vitro is increased in human diabetes $[3,19]$. The biochemical basis of the decreased elimination rate is more difficult to establish, particularly as the studies in vitro with liver slices give no indication of such defect [1]. The two studies on glycerol elimination in diabetes did not reveal any evidence of a defect of removal, but, on the contrary, suggested an increased rate of efflux at glycerol loads of such magnitude that the elimination follows zero order kinetics $[13,24]$.

The abnormally low plasma glycerol level observed in diabetics after an oral glycerol load is not easily interpreted. On the basis of the lower elimination rate found in the intravenous test and of the higher endogenous glycerol mass in diabetes, a high serum glycerol response should be expected after oral administration of glycerol. As the actual results obtained were quite opposite to this expectation there must be something abnormal in the pathway of glycerol from the lumen of the gut to the general circulation.

It is not known whether glycerol is transported actively or diffuses passively through the intestinal wall. The rapid intestinal absorption, observed in the present study and by others $[22,13]$, may indicate active absorption. In support of this concept, the activity of enzymes necessary to phosphorylate glycerol (glycerol kinase) and to split the $\alpha$-glycerophosphate formed (phosphatase) is high in gut mucosa $[6,8]$. Other reactions, apart from phosphorylation, have been discussed by Haessler and Issembacher [8] as the first step in the metabolization of glycerol by gut mucosa, but they were considered less probable. Esterification of glycerol to lipids and oxidation to $\mathrm{CO}_{2}$ have recently been shown to occur already in intestinal mucosa [14, $21,26]$. The ability of the gut to convert glycerol to glucose, although probable, has, so far as we are aware, never been demonstrated. After absorption free glycerol is transported to the liver [7].

The concentration of glycerol in the general circulation after its oral administration is determined at least by the following kinetic parameters: 1 . the velocity of glycerol transport across the intestinal wall; 2. the capacity to remove glycerol by metabolic routes before its appearance at the point of circulation where the samples are drawn (the active removal sites are the intestinal mucosa and the liver); 3 . the rate of distribution of glycerol from blood to the glycerol space $\left(k_{1}\right)$; and 4 . the general elimination rate of glycerol after its equilibration $\left(k_{2}\right)$. As the measured parameters 3 and 4 do not account for the observations in diabetes, abnormalities must be sought in the processes 1 and 2 . As both absorption and elimination of glycerol are extremely rapid processes fairly small changes in either of these rates may cause profound alterations in the serum glycerol levels during the oral test. Unfortunately, we have no knowledge of the rate of glycerol flow from the intestinal lumen in to the portal circulation. The appearance of glycerol in the portal venous blood is retarded when the rate of the absorption process itself is decreased, or when increased amounts are transformed to other compounds in the intestinal mucosa. A real malabsorption of glycerol is unlikely, but the other possibility is supported by the recent finding of TYOR and BRICE [26] that formation of lipids from glycerol is enhanced in vitro in the intestinal mucosa of diabetic subjects. It may also be of significance in this context that the oral glycerol caused an increase of blood glucose in insulinrequiring diabeties.

In contrast to normolipemic diabeties, hyperlipemic patients with secondary diabetes showed high peak levels of serum glycerol on the oral loading. A similar pattern of glycerol absorption has been found in one hyperlipemic case with normal glucose metabolism. If glycerol absorption is normal, this would be the expected result since in hyperlipemia the endogenous glycerol mass was shown to be increased and the fractional disappearance rate decreased. Thus, one need not assume the presence of an increased rate of intestinal glycerol absorption.

\section{References}

[1] Ashmore, J., A.E. Renold, F.B. Nesbett and A.B. Hastings: Studies on carbohydrate metabolism in rat liver slices. V. Glycerol metabolism in relation to other substrates in normal and diabetic tissue. J. biol. Chem. 215, 153-161 (1955).

[2] Borchgrevink, C.F., and R.J. HAvel: Transport of glycerol in human blood. Proc. Soc. exp. Biol.113, $946-949$ (1963).

[3] CARLson, L.A., and J. ÖstinanN : In vitro studies on the glucose uptake and fatty acid metabolism of human adipose tissue in diabetes mellitus. A preliminary report. Acta med. scand. 174, 215-218 (1963).

[4] -, and L.B. WADSTRöM: Determination of glycerides in blood serum. Clin. chim. Acta 4, 197-205 (1959).

[5] - , and L. Orö: Studies on the relationship between the concentration of plasma free fatty acids and glycerol in vivo. Metabolism 12, 132-142 (1963).

[6] Clark, B., and G. HüBscher: Glycerokinase in mucosa of the small intestine of the cat. Nature 195, $599-600(1962)$.

[7] Dokrschuk, A.P.: Some studies on the metabolism of glycerol-1-C 14 . J. biol. Chem. 193, 39-44 (1951).

[8] H_AEsster, H.A., and K.J. IsselbaChER: The metabolism of glycerol by intestinal mucosa. Biochem. biophys. Acta 73, 427-436 (1963).

[9] HAGEN, J.H.: The effect of insulin on concentration of plasma glycerol. J. Lipid. Res. 4, 46-51 (1963).

[10] - J.A. MoorHouse and J. STEINBERG: Effect of insulin on plasma glycerol in man. Metabolism 12, 346-351 (1963).

[11] var HaNDei, E., and D.B. Zilversuit: Mieromethod for the direct determination of serum triglycerides. J. Lab. clin. Med. 50, 152-157 (1957).

[12] Havel, R.J., and L.A. CARLSON : Comparative turnover rates of free fatty acids and glycerol in blood of dogs under various conditions. Life Sci. 2, $651-$ $658(1963)$.

[13] HoLst, E.J.: Glycerol oxidation in the animal organism. Acta physiol, scand. 7, 69-79 (1944). 
[14] HoLT, P.R.: Utilization of glycerol-C ${ }^{14}$ for intestinal glyceride esterification. Studies in a patient with chyluria. J. clin. Invest. 43, 349-356 (1964).

[15] HYvÄRINEN, A., and E.A. NTKkIL : Specific determination of blood glucose with o-toluidine. Clin. chim. Acta 7, $140-143(1962)$.

[16] Jungas, R.L., and E.G. Bats: An anti-lipolytic action of insulin on adipose tissue. Fed. Proc. 21, 202 (1962).

[17] KжкKI, M.: Serum protein turnover in experimental hypo- and hyperthyroidism. Acta endocr. 46, suppl. 91 (1964).

[18] NTKKIL ̈̈, E.A., and K. OJALA: Gluconeogenesis from glycerol in fasting rats. Life Sci. 3, 243-249 (1964).

[19] Ö́sTMAN, J.: Studies in vitro on fatty acid metabolism of human subcutaneous adipose tissue in diabetes mellitus. Acta med. scand. 177, $639-655$ (1965).

[20] Pearson, S., S. Stern and T. McGavack: A rapid accurate method for the determination of total serum cholesterol. Analyt. Chem. 25, 813-814 (1953).

[21] SaUnders, D.R., and A.M. Dawson: Studies on the metabolism of glycerol by the small intestine in vitro and in vivo. Biochem. J. 82, 477-483 (1962).

[22] Schwarz, K., P. BotTermann, G. Claussen, K. KoPETZ and K.P. EYMER: Untersuchungen über die
Resorption und die biologische Halbwertszeit von Glycerin beim Menschen. Klin. Wschr. 40, 1183-1187 (1962).

[23] Sharrir, E., and E. Gorin: Release of glycerol in conditions of fat mobilization and deposition. Metabolism 12, 580-587 (1963).

[24] STRACK, E., H. THEILE and H. ReINHold : Über den Umsatz von Glycerin beim alloxandiabetischen $\mathrm{Ka}$ ninchen. Z. ges. exp. Med. 134, 407-422 (1961).

[25] Trout, D.L., E.H. Estes, JR., and S.J. FrredBerg: Titration of free fatty acids of plasma: a study of current methods and a new modification. J. Lipid. Res. 1, 199-202 (1960).

[26] Tyor, M.P., and R.S. Brice: Measurements of lipid esterification by intestinal mucosa of patients with diabetes. J. clin. Invest. 43, 1276 (1964).

[27] Wifland, O.: Eine enzymatische Methode zur Bestimmung von Glycerin. Biochem. Z. 329, 313-319 (1957).

Dr. Risto Pelionen

Third Department of Medicine, University Central Hospital

Helsinki 29, Finland 